This is an Author's Accepted Manuscript of an article published by Edinburgh

University Press in Edinburgh Law Review. The Version of Record is available online at: https://www.euppublishing.com/doi/abs/10.3366/elr.2016.0321

\title{
T B Smith and Max Rheinstein: Letters from America
}

\author{
Alisdair D J MacPherson*
}
A. INTRODUCTION
B. T B SMITH
(1) A Special Relationship?
(2) The law reformer
(3) The legal nationalist?
(4) Making it in America
(5) Sources of law
(6) Scholars and teaching
E. CONCLUSION

C. THE MAX RHEINSTEIN PAPERS

D. T B SMITH AND MAX RHEINSTEIN: THE LETTERS

\section{A. INTRODUCTION}

T B Smith was, and remains, a controversial figure in Scots law and his views, influence, and legacy are still debated. ${ }^{1}$ What is inarguable, however, is that he was one of the towering

\footnotetext{
* PhD candidate, University of Edinburgh and Max Planck Institute for Comparative and International Private Law, Hamburg. I am grateful to George Gretton, Scott Wortley, Reinhard Zimmermann, and the anonymous peer reviewer for their helpful comments on earlier drafts of this article. I would also like to thank the Clark Foundation for Legal Education, the Edinburgh Legal Education Trust, and the Max Planck Society for their support.

${ }^{1}$ See e.g. the essays in E Reid and D L Carey Miller (eds), A Mixed Legal System in Transition: T B Smith and the Progress of Scots Law (2005). For a highly critical perspective on T B Smith, see D J Osler, "The Fantasy Men” Rechtsgeschichte 10 (2007) 169. Smith's views could be divisive, including with colleagues, see e.g. H L MacQueen, “Memoir of Professor William Adam Wilson, M.A., LL.B, LL.D, FRSE” in H L MacQueen (ed), Scots Law into the $21^{\text {st }}$ Century. Essays in Honour of W. A. Wilson (1996) 6.
} 
Scottish legal figures of the second half of the twentieth century. Lord Hope, for example, has described him as: "without doubt the outstanding Scots lawyer of his generation”. ${ }^{2}$

Smith's wide-ranging published work has been subjected to rigorous analysis. ${ }^{3}$ By contrast, his unpublished writings have not survived or continue to lie undiscovered and undiscussed. An exception to this is Professor MacQueen's recent work on the relationship between Smith and David Daube, which includes an examination of correspondence between the men. ${ }^{4}$ The present article reflects upon correspondence between Smith and another leading international legal scholar of the twentieth century: Max Rheinstein. ${ }^{5}$

The letters exchanged by Rheinstein and Smith provide us with an insight into their relationship and offer a series of snapshots regarding their respective views and interests. Nevertheless, the correspondence sheds more light upon Smith than Rheinstein, not least because it discloses that the connection held greater utility for Smith, and therefore the Scot will be the primary focus of this article.

Smith's presence on the international stage is referred to by Professor Black, who states that: “Tom Smith was undoubtedly the representative and ambassador of Scots law who was best known to lawyers furth of the jurisdiction." ${ }^{6}$ Crucial components of Smith’s identity and reputation were the images of himself and of Scots law that he sought to present to individuals abroad.

It has been suggested that Smith's international success, in promoting Scots law and Scottish legal scholarship, was based more upon his contacts than his writing. ${ }^{7}$ Unfortunately, the general absence of identified correspondence written by Smith makes it difficult to ascertain precisely how he utilised his system of contacts. The Rheinstein-Smith letters therefore offer a welcome opportunity to examine how Smith actually used a connection with a distinguished

\footnotetext{
${ }^{2}$ Rt Hon Lord Hope, “Foreword”, in D L Carey Miller and D W Meyers (eds), Comparative and Historical Essays in Scots Law: A Tribute to Professor Sir Thomas Smith QC (1992) xi.

${ }^{3}$ Again, see e.g. Reid \& Carey Miller (eds), Mixed Legal System (n 1). Within this source, a comprehensive bibliography of Smith's published work can be found: R G Anderson, "Professor Sir Thomas Smith QC - a bibliography” (302 ff). See also Carey Miller \& Meyers (eds), Comparative and Historical Essays (n 2) for a series of essays in tribute to Smith.

${ }^{4}$ H L MacQueen, “David Daube and T B Smith”, in E Metzger (ed), David Daube: A Centenary Celebration (2010) 11; H L MacQueen, “A Friendship in the Law: David Daube and T B Smith” (2012-13) 87 Tulane LR 811.

${ }^{5}$ Smith's relationship with Rheinstein was, however, markedly different from his relationship with Daube, one major reason being that Smith and Daube were close colleagues for a number of years. The Rheinstein-Smith correspondence is held within Rheinstein, Max. Papers, Special Collections Research Center, University of Chicago Library; hereafter referred to as the "Papers". I am grateful to the Special Collections Research Center, at the University of Chicago Library, for making these papers available to me.

${ }^{6}$ R Black, "Professor Emeritus Sir Thomas Broun Smith QC 1915-1988”, in The Laws of Scotland: Stair Memorial Encyclopaedia vol 25 (1989) xiii.

${ }^{7}$ D M Walker, “Smith, Sir Thomas Broun (1915-1988)” in H C G Mathew and B Harrison (eds), Oxford Dictionary of National Biography vol 51 (2004) 347.
} 
international academic. The documentation provides us with evidence of Smith in the role of law reformer, as a champion of Scots law abroad, and as an effective network-builder during a key period in his professional life (1955-1964).

\section{B. T B SMITH}

T B Smith's biographical details have been narrated in many publications. ${ }^{8}$ Perhaps surprisingly, the Scot began his legal career in England. He graduated with a degree in jurisprudence from Oxford in 1937 before being called to the bar at Gray’s Inn. After serving in the Second World War, Smith returned to Scotland, and began practicing as an advocate in 1947. The fact that Smith came to Scots law after studying and practicing English law has been appropriately described as "a positive incitement to a comparative approach to law". 9 Smith, quite typically, attributed such an approach to his possession of “a Scots lawyer's inescapable concern for comparative solutions". ${ }^{10}$

By the time Smith was writing the first of the letters to Rheinstein, held in the Papers, he was already Professor of Scots Law at the University of Aberdeen. He had occupied this position since $1949 .{ }^{11}$ In the period covered by the correspondence, Smith moved to Edinburgh, becoming Professor of Civil Law there (1958), ${ }^{12}$ and also held visiting positions at the Universities of Tulane (1957-1958), Cape Town (1958), Witwatersrand (1958) and Harvard (1962-1963).

Between 1954 and 1965, Smith was also an active member of the Law Reform Committee for Scotland ("LRCS"). ${ }^{13}$ As we shall see, some of his correspondence with

\footnotetext{
${ }^{8}$ See, e.g., the biographical articles cited in Anderson (n 3) at 311.

${ }^{9}$ K G C Reid, "While one hundred remain: T B Smith and the progress of Scots law” in Reid \& Carey Miller (eds), Mixed Legal System (n 1) 3.

${ }^{10}$ T B Smith, Property Problems in Sale (1978) Preface [7].

${ }^{11}$ His appointment had been announced the previous year: 1948 SLT (News) 155.

${ }^{12}$ Smith's famous inaugural lecture was published as T B Smith, "Strange gods: the crisis of Scots law as a Civilian system” 1959 Jur Rev 119. It was republished at T B Smith, Studies Critical and Comparative (1962)

72. In a letter to Rheinstein, Smith noted that he had "left Aberdeen with regret": letter from T B Smith to Max Rheinstein dated 23 October 1958 in Papers [Box 44, Folder 20]. In response, Rheinstein wrote that he remembered Aberdeen "as a most charming place" but he was even more enamoured with Edinburgh, describing it as "one of the most beautiful cities in the world": copy letter from Rheinstein to Smith dated 4 November 1958 in Papers [Box 44, Folder 20].

${ }^{13}$ Lord Hunter, "Professor Emeritus Sir Thomas Smith, Q.C. - A personal appreciation” 1982 JR 5 at 9, Lord Hope of Craighead, “Do we still need a Law Commission?” (2006) EdinLR 10 at 16, and S Wilson Stark, “The longer you can look back, the further you can look forward: the origins of the Scottish Law Commission” (2014) EdinLR 59 at 66 (at 66), all state that, despite becoming a Commissioner, Smith remained a member of the LRCS until its formal demise in 1970. However, archived LRCS documents suggest that Smith may have resigned shortly after his appointment as a Commissioner. In one letter, Smith proposed to offer his resignation (and suggested David Walker as a suitable replacement) - letter from Smith to J H Gibson dated 21 June 1965 in
} 
Rheinstein involved him seeking information in this capacity. In 1965 Smith became a Commissioner of the newly-established Scottish Law Commission. ${ }^{14}$ After vacating the Scots Law Chair at Edinburgh in 1972, ${ }^{15}$ he was a full-time member of the Commission until 1980. His final years, from 1981 until his death in 1988, were spent as general editor of The Laws of Scotland: Stair Memorial Encyclopaedia.

The available correspondence between Rheinstein and Smith covers a productive time in terms of Smith's published work. Arguably his most significant offerings to scholarship, British Justice: the Scottish Contribution ${ }^{16}$ (his Hamlyn Lectures), Studies Critical and Comparative, ${ }^{17}$ and A Short Commentary on the Law of Scotland, ${ }^{18}$ were all published in this period. The Papers contain some interesting discussion regarding the publication of the second of these titles. ${ }^{19}$

This was also the period within which Smith first developed his views on the potential significance of mixed legal systems for Scots law. From the mid-1950s he read important literature from other such systems and this, as well as the time he spent in Louisiana and South Africa in 1957 and 1958, caused him to identify the commonalities between these systems and Scotland. ${ }^{20}$ As Professor Cairns notes, for Smith the mixed legal system concept offered a means by which Scots law could be protected from the influence of English law. ${ }^{21}$ Smith believed that such protection could be derived from embedding Scotland firmly within an identifiable family of mixed legal systems. He considered the Civil Law elements of Scots law to be superior to those deriving from the English Common Law and thought that the former

\footnotetext{
NRS AD61/1. In later documents Smith is not listed as a member of the LRCS, see e.g. copy letter from J H Gibson to R B Laurie, Law Society of Scotland, dated 27 February 1968 in NRS AD61/1. In any event, little formal work was done by the LRCS after the establishment of the SLC: the Fourteenth Report of the Law Reform Committee for Scotland: the position in relation to diligence of creditors of goods in the possession of, but not belonging to, a debtor (Cmnd 2343: 1964) was its final issued report.

${ }^{14}$ For some discussion of Smith and the establishment of the Scottish Law Commission, see Wilson Stark (n 13) at 66-68.

${ }^{15}$ He had moved from the Chair of Civil Law to this Chair in 1968.

${ }^{16}$ T B Smith, British Justice: the Scottish Contribution (1961).

${ }^{17}$ T B Smith, Studies Critical and Comparative (1962).

${ }^{18} \mathrm{~T}$ B Smith, A Short Commentary on the Law of Scotland (1962).

19 See below at 000 .

${ }^{20}$ Reid (n 9) at 9 ff. And see V V Palmer, "Travelling the high road with T B Smith: nationalism and internationalism in the defence of the Civilian tradition” in Reid \& Carey Miller (eds), Mixed Legal System (n 1) at $267 \mathrm{f}$. For examples of Smith’s work highlighting the mixed legal system links, see e.g. "The common law cuckoo: problems of 'mixed' legal systems with special reference to restrictive interpretations in the Scots law of obligations” (1956) BSALR 147, republished at Smith, Studies Critical (n 17) 89; his "Introduction” to Studies Critical (n 17) ix; and "Scots law and Roman-Dutch law: a shared tradition” (1959) Acta Juridica 36, republished at Smith (n 17) 46.

${ }^{21} \mathrm{~J}$ W Cairns, "Development of comparative law in Great Britain”, in M Reimann and R Zimmermann (eds), The Oxford Handbook of Comparative Law (2006) 167.
} 
should be nurtured at the expense of the latter. In his view, this could be achieved by following examples in other mixed systems. ${ }^{22}$

With respect to Smith's comparative law approach and methodology, Professor Visser considers him to be a member of the "broad church of functionalism" but within "a niche which is a very specific variant of the catholic approach”. ${ }^{23}$ Max Rheinstein was a notable early proponent of the functionalist approach and Visser identifies "echoes" of Rheinstein in the manner in which Smith had regard to the roles of judges and the legal profession in the development of a legal system. ${ }^{24}$ Whether Rheinstein's work directly influenced Smith, and the extent to which this was so, appears largely indeterminable. What is certain is that building a professional relationship with Rheinstein would have been an attractive proposition for Smith: the German was a well-connected and internationally prominent scholar of comparative law.

\section{THE MAX RHEINSTEIN PAPERS}

Max Rheinstein (1899-1977) was one of the greatest comparative lawyers of the twentieth century. ${ }^{25}$ He was born and educated in Germany before travelling to the USA in September 1933 on a Rockefeller Foundation fellowship. By the time he departed for the USA he was a Privatdozent and was working with Ernst Rabel $^{26}$ at the Kaiser-Wilhelm-Institut für

\footnotetext{
${ }^{22}$ See, e.g., K G C Reid, “The idea of mixed legal systems” (2003-4) 78 Tulane LR 5 at 11 ff. The "neocivilian” views held by Smith have been heavily criticized by some: see e.g. Osler (n 1) $172 \mathrm{ff}$ and A Rodger, “'Say not the struggle naught availeth': the costs and benefits of mixed legal systems” (2003-4) 78 Tulane LR 419 at 422, who characterize Smith's vision as a "fantasy”. For discussion of the "Cooper-Smith ideology", see I D Willock, “The Scottish Legal Heritage Revisited”, in J P Grant (ed), Independence and Devolution. The Legal Implications for Scotland (1976) 1; H L MacQueen, "Two Toms and an Ideology for Scots Law: T B Smith and Lord Cooper of Culross”, in Reid \& Carey Miller (eds), Mixed Legal System (n 1) 44; H L MacQueen, "Legal Nationalism: Lord Cooper, Legal History and Comparative Law”, (2005) EdinLR 395, and the literature cited therein.

${ }^{23}$ D Visser, “The ties that bind: T B Smith as a comparative lawyer”, in Reid \& Carey Miller (eds), Mixed Legal System (n 1) 272 at 285.

${ }^{24}$ Ibid at $286 \mathrm{f}$.

${ }^{25}$ For discussion of his life (that included military service for Germany in the First World War and a role in the rebuilding of Germany immediately after the Second World War) and his academic work see, e.g., N Rinck, Max Rheinstein - Leben und Werk (2011); W Fr von Marschall, “Max Rheinstein”, in M Lutter, E C Stiefel and M H Hoeflich (eds), Der Einfluß deutscher Emigranten auf die Rechtsentwicklung in den USA und in Deutschland (1993) 333; and, in the same publication, M A Glendon, “The influence of Max Rheinstein on American law” 171. The Festschrift in honour of Rheinstein is also of interest: E von Caemmerer, S Mentschikoff and K Zweigert (eds) Ius privatum gentium: Festschrift für Max Rheinstein zum 70 Geburtstag am 5 Juli 19692 vols (1969); and see the tributes to Rheinstein at (1977-8) 45 U Chi LR $511 \mathrm{ff}$.

${ }^{26}$ (1874-1955). See, e.g., I Schwenzer, "Development of comparative law in Germany, Switzerland, and Austria”, in Reimann \& Zimmermann (eds), Oxford Handbook (n 21) 69 at 77 ff, and the sources cited therein, for an indication of Rabel's influence on comparative law. For Rheinstein's views on Rabel, see M Rheinstein, "Ernst Rabel”, in H Dölle, M Rheinstein and K Zweigert (eds), Rechtsvergleichung und internationales Privatrecht, Festschrift für Ernst Rabel vol I (1954) 1 and M Rheinstein, “In Memory of Ernst Rabel” (1956) 5 AJCL 185.
} 
ausländisches und internationales Privatrecht in Berlin. ${ }^{27}$ Given his Jewish background, Rheinstein seems to have felt compelled to leave Nazi Germany, and was thus one of many emigrant scholars in this period. His relative youthfulness, comparative law expertise, and familiarity with the Common Law were important factors that helped him to remain in the USA once his scholarship had expired, and thereafter to flourish. ${ }^{28}$

After spending time at Columbia and Harvard Universities as part of his fellowship, Rheinstein acquired a visiting position at the University of Chicago in 1935. He became Max Pam Professor of Comparative Law there in 1936, first as an assistant professor, then as associate professor, before finally becoming full professor in 1942. He retired from the latter position in 1968. Rheinstein also held visiting professorships at various universities, such as Cambridge, his location when Smith wrote the first piece of their correspondence within the Papers. $^{29}$

Rheinstein was academically prolific and his published work is rich and varied. ${ }^{30}$ It is only fitting then that the University of Chicago, the institution to which he was so closely connected, holds a vast array of papers documenting his career. The Papers contain biographical information, writings such as lectures and addresses, articles and reviews, course materials, and subject files for meetings and projects.

Also contained within the Papers is a large volume of correspondence. Many of the correspondence files are labelled with the names of renowned lawyers from the last century, including René David, J C de Wet, Roscoe Pound, Ernst Rabel, and Konrad Zweigert. ${ }^{31}$ The calibre of such correspondents reflects Rheinstein's status as a leading jurist of the age. The Papers are a valuable resource for the study of modern legal history, particularly within the context of comparative law. Most pertinently for the purposes of this article, we find, within the constellation of Rheinstein's correspondents, T B Smith. ${ }^{32}$

\section{T B SMITH AND MAX RHEINSTEIN: THE LETTERS}

\footnotetext{
${ }^{27}$ Now the Max-Planck-Institut für ausländisches und internationales Privatrecht based in Hamburg. As well as the sources at n 25 see K Graham, “The Refugee Jurist and American Law Schools, 1933-1941” (2002) 50 AJCL 777 at 795.

${ }^{28}$ See Schwenzer (n 26) at 83, Glendon (n 25) at $171 \mathrm{f}$, and Graham (n 27) at $795 \mathrm{f}$.

${ }^{29}$ For a tabular summary of events and achievements in Rheinstein's life see Rinck, Rheinstein (n 25) at $373 \mathrm{ff}$.

${ }^{30}$ A comprehensive bibliography of the writings of Rheinstein is available: ibid at $327 \mathrm{ff}$. For a selected collection of his writings, see M Rheinstein, Gesammelte Schriften, H G Leser (ed) 2 vols (1979).

${ }^{31}$ Guide to the Max Rheinstein Papers 1869-1977, University of Chicago Library (2006), available at: http://www.lib.uchicago.edu/ead/rlg/ICU.SPCL.RHEINSTEIN.pdf (last accessed 17 June 2015).

${ }^{32}$ In Papers [Box 44, Folder 20]. Hereafter, all references to Papers are to Box 44, Folder 20.
} 
The Rheinstein-Smith letters span the period from 21 October 1955 until 7 December 1964. In total, there are fifteen Rheinstein-Smith letters (or copies of such letters) held in the Papers; eleven sent by Smith and four from Rheinstein. All but three of the letters were sent between 23 October 1958 and 8 February 1961. In addition, the Papers contain not only direct communication between Rheinstein and Smith but also letters and documents relating to Smith and copies of third party correspondence with him, all of which are referred to below.

It is questionable whether written communications between Rheinstein and Smith were commenced by the first letter, as this document suggests that there was already a degree of familiarity between the men. Similarly, the absence of finality in the last missive means that it is difficult to know whether it was followed by others. Even within the time period covered there are indications of missing correspondence as well as significant time gaps. ${ }^{33}$ Nevertheless, the contents of the available correspondence are of interest.

\section{(1) A Special Relationship?}

The correspondence between Rheinstein and Smith is almost entirely professional in its focus and is less personalised and intimate than, for example, Smith's communications with Arthur E Sutherland or David Daube. ${ }^{34}$

In the first letter Smith sought to confirm the arrangements for Rheinstein to travel from Cambridge to Aberdeen to lecture on the "Factors making for the Stability of Marriage" on 6 December 1955. ${ }^{35}$ The subject was apparently one of at least two subjects suggested by Rheinstein. From the letter it is clear that Smith and at least some of his colleagues had

\footnotetext{
${ }^{33}$ See, e.g., the letter from Smith to Rheinstein dated 18 June 1959 in the Papers in which Smith is apparently responding to points raised by Rheinstein, but there is not a copy of an earlier corresponding letter in the Papers. With respect to time gaps, there is, for example, a break of over three years between the first letter and the second, dated 23 October 1958.

${ }^{34}$ See Sutherland, Arthur E, Papers, 1923-1972, [Series IX, 55-5], Harvard Law School Library (hereafter, Sutherland Papers) and, for Smith’s correspondence with Daube, see MacQueen (n 4). For biographical information about Sutherland (1902-1973), see the tributes to him at (1973) 86(6) Harv LR 933 ff. Smith worked alongside Sutherland during his year at Harvard and, of course, Daube was a close colleague of Smith at Aberdeen, although both men appear to have been on friendly terms with Smith before working with him. By contrast, Rheinstein and Smith never worked together.

${ }^{35}$ Letter from Smith to Rheinstein dated 21 October 1955 in Papers. The letter was addressed to Professor Rheinstein at Madingley Hall, Cambridge. Reference is made in this letter to Smith's previous correspondence with Hamson (presumably Professor Charles Hamson: see J A Jolowicz, "Hamson, Charles John Joseph (19051987)" rev. Oxford Dictionary of National Biography (2004), http://www.oxforddnb.com/view/article/40091, last accessed 17 June 2015 (subscription required). Smith also mentioned Rheinstein's intention to meet with Wortley in Manchester (almost certainly B A Wortley (1907-1989): see "Professor B A Wortley" The Times (13 June 1989)). An article by Rheinstein on a topic similar to the proposed lecture was published as M Rheinstein, "The law of divorce and the problem of marriage stability" (1955-6) 9 Vand LR 633. It seems likely that the lecture went ahead as planned: Smith intimated the details of the lecture to an Aberdeen University Faculty of Law meeting on 17 November 1955 - University of Aberdeen, Faculty of Law Minutes (1949-1958), Aberdeen University School of Law. I express thanks to Professor David Carey Miller for this reference.
} 
previously met Rheinstein, but where any such meeting(s) had taken place - in Aberdeen or elsewhere - is not disclosed. ${ }^{36}$ Smith would, no doubt, have considered a lecture from a distinguished figure such as Rheinstein to be notable for Aberdeen University. Inviting Rheinstein to Aberdeen may be viewed as part of Smith's wider efforts to expose Scots law to international influences and also as an attempt to build a firmer connection with Rheinstein.

Later correspondence discloses that Rheinstein was keen for Smith to give a lecture in Chicago. While based at Harvard in 1962-1963, Smith corresponded with Associate Dean Dallin H Oaks of Chicago Law School. ${ }^{37}$ In the first letter, Oaks wrote that Rheinstein and other faculty members would be "keenly disappointed" if Smith did not visit. ${ }^{38}$ It was proposed that Smith could deliver a lecture in Chicago on 5 April 1963. ${ }^{39}$ After Smith had apparently offered a number of potential topics for the lecture, ${ }^{40}$ Oaks noted that Rheinstein, in order of preference, favoured the "Saint Ninian's Isle case" ${ }^{41}$, followed by a proposed family law topic and then a suggested criminal law lecture. Apparently other individuals had suggested that Smith's "remarks on the criminal process" would be of more interest to students. ${ }^{42}$ The three mentioned possibilities demonstrate the diversity of Smith's scholarly interests. ${ }^{43}$

Elsewhere in the correspondence, the parties mention their interest in seeing each other. In November 1958 Rheinstein expressed his great “regret” that there had been no opportunity to meet with Smith when the Scot had been in the USA and that he hoped they could meet again soon. ${ }^{44}$ In a letter dated 3 June 1959 Smith enquired when Rheinstein would be re-visiting

\footnotetext{
${ }^{36}$ Smith stated in the letter of 21 October 1955: "my colleagues and myself will be very glad to see you again...”.

${ }^{37}$ See the copy letters from D H Oaks to Smith dated 24 October 1962 and 4 December 1962; and the copy letters from Smith to Oaks dated 31 October 1962 and 6 December 1962. See also the memos from Oaks to Rheinstein dated 1 November 1962 and 7 December 1962, enclosing correspondence with Smith and the memo from Rheinstein to Oaks dated 7 November 1962. All of this correspondence is in the Papers.

${ }^{38}$ Copy letter dated 24 October 1962 (n 37).

${ }^{39}$ Copy letter dated 4 December 1962 (n 37).

${ }^{40}$ The Papers do not contain a letter from Smith outlining the proposed topics in detail.

${ }^{41}$ Lord Advocate v Aberdeen University and Budge 1963 SC 533. Smith acted as counsel for the unsuccessful second defender in this famous case involving the, then recently discovered, St Ninian's Isle Treasure. Smith subsequently wrote about the case on a number of occasions. See, e.g., T B Smith, “The St Ninian’s Isle treasure - a legal riddle in the sands" (1964) Acta Juridica 187; and T B Smith, “The law relating to the treasure” in A Small, C Thomas, and D M Wilson (eds), St Ninian's Isle and its Treasure vol 1 (1973) 149. Smith was still interested in the matter at the time of his death: "Editorial Excursus by the Late Sir Thomas Smith", in The Laws of Scotland: Stair Memorial Encyclopedia vol 24 (1989) 219. In addition, some documentation relating to the case was retained by Smith and is available at T B Smith Collection, Edinburgh University Library (Special Collections, GB237/Coll-1250) (Box 9/17 formerly Box 4/F5). Professor Carey Miller discusses Smith’s involvement in the case in D L Carey Miller, “T B Smith’s Property” in Reid \& Carey Miller (eds), Mixed Legal System (n 1) 173 at 192 ff. In his letter of 6 December 1962 (n 37), Smith stated that he hoped to have further consultations regarding the "St Ninian's Treasure" in Scotland later that month and that he had recently completed an opinion for the case.

${ }^{42}$ Copy letter dated 4 December 1962 (n 37).

${ }^{43}$ Unfortunately, it has not been possible to confirm that the lecture took place.

${ }^{44}$ Copy letter dated 4 November 1958 (n 12).
} 
Scotland, noting that his previous visit, to Aberdeen, had been "loved". ${ }^{45}$ Smith also declared enthusiastically: "Edinburgh wants you!". ${ }^{46}$ The possibility of a meeting in the USA, if they could not meet in Europe first, was raised by Smith in late 1960 when he expressed his hope of teaching at Harvard Law School in 1962-1963. ${ }^{47}$ In response, Rheinstein stated that the prospect of Smith visiting the country was "delightful”. ${ }^{48}$ Such comments create the impression that Smith and Rheinstein looked forward to their meetings together and got on well on a personal basis. It is, however, difficult to separate out true personal sentiment from simple politeness within a professional context such as this. Furthermore, we do not even know on how many occasions Smith and Rheinstein met.

Over time, though, the two scholars do seem to have felt increasingly familiar with one another. Indeed, this is perhaps most elegantly highlighted in the final two letters which open with the informal "Dear Max" and "Dear Tom" respectively, in place of their surnames which had been used in earlier letters. ${ }^{49}$ This may have symbolised a milestone in their personal relationship.

There are some expressions of admiration and respect within the correspondence. When Smith initially referred to the difficulty of finding somebody appropriate to deliver his classes at Edinburgh for the duration of his time at Harvard, ${ }^{50}$ Rheinstein responded: "[t]he problem of finding some one to replace you at Edinburgh is not easy. As a matter of fact, I regard it as impossible to find any one who could really replace T. B. S." 51 It is not obvious whether this was simply a reference to Smith’s ebullient character or also a reference to his proficiency as an academic.

Rheinstein also described Smith as "the most prominent legal scholar in Scotland” when he wrote to a third party to request information for Smith. ${ }^{52}$ This statement is in accordance with the generally-held perception of Smith as the internationally best-known Scottish lawyer of the time. Smith was also prepared to offer compliments. Although his reference to Rheinstein

\footnotetext{
45 This may be a reference to the lecture visit that Smith was seeking to confirm with Rheinstein in the first letter.

${ }^{46}$ Letter from Smith to Rheinstein dated 3 June 1959 in Papers.

${ }^{47}$ Letter from Smith to Rheinstein dated 19 November 1960 in Papers. On an earlier occasion, Smith had stated that he would be unable to meet Rheinstein "on the Continent”, no doubt a reference to continental Europe: see letter dated 18 June 1959 (n 32).

${ }^{48}$ Copy letter from Rheinstein to Smith dated 5 December 1960 in Papers.

${ }^{49}$ Letter from Smith to Rheinstein dated 23 November 1964 in Papers; copy letter from Rheinstein to Smith dated 7 December 1964 in Papers. The earlier letters already suggest a degree of familiarity through the use of the greetings "My dear Rheinstein” and “My dear Smith” rather than the more formal "Dear Professor...”.

$50 \mathrm{~N} 47$.

${ }^{51} \mathrm{~N} 48$.

${ }^{52}$ Copy letter from Rheinstein to H Wechsler dated 9 June 1959 in Papers. The copy letter is incorrectly addressed to "Wexler".
} 
as "the most eminent comparatist in the United States" 53 must be seen within the context of seeking publishing advice from Rheinstein, it is reasonable to believe that the sentiment was genuinely held. ${ }^{54}$

The correspondence therefore suggests that the Smith-Rheinstein relationship was marked with some personal warmth and mutual respect. However, this should not be misinterpreted as disclosing a relationship that was especially close. Each man communicated with other jurists with whom they were closer both professionally and personally. And, as we shall see, the contents of the correspondence give the impression of a relationship that was relatively formal and principally functional. Smith was the more active corresponding party and felt comfortable to ask Rheinstein for his assistance on particular issues for which he believed Rheinstein was well placed to help. In fact, this was the principal stimulus for the exchange of letters.

\section{(2) The law reformer}

T B Smith was engaged in the reform of Scots law for a significant part of his legal career. ${ }^{55}$ One project that he was heavily involved in, as a member of the LRCS, led ultimately to the introduction of the floating charge in Scots law, by way of the Companies (Floating Charges) (Scotland) Act 1961. Given Smith’s general antipathy to English legal influence, his support for an adapted version of an English equitable security device appears surprising. ${ }^{56}$

Prior to producing their report recommending the introduction of the floating charge, the LRCS consulted various prominent foreign experts including Max Rheinstein. ${ }^{57}$ Smith wrote to Rheinstein on 23 October 1958 notifying him of the LRCS project and requested his input. ${ }^{58}$ At that time, the project was still limited to the reform of security over moveable property. ${ }^{59}$ Smith informed Rheinstein that the LRCS was considering the "desirability" of

\footnotetext{
${ }^{53}$ Letter from Smith to Rheinstein dated 20 January 1961 in Papers.

${ }^{54}$ For example, the fact that Smith wrote to Rheinstein seeking his advice on this matter (and others) supports the veracity of the statement.

55 See above.

${ }^{56}$ For discussion of Smith and the introduction of the floating charge see Reid (n 9) at 17; and G L Gretton, "The Rational and the National: Thomas Broun Smith” in Reid \& Carey Miller (eds), Mixed Legal System (n 1) 30 at 39 ff. As Professor Gretton suggests, Smith was far more comfortable with convergence between Scots law and English law in commercial law matters than in other areas.

${ }^{57}$ See Eighth Report of the Law Reform Committee for Scotland: the constitution of security over moveable property; and floating charges (Cmnd 1017: 1960) at para 3.

${ }^{58}$ Letter dated 23 October 1958 (n 12). It has not been possible to locate copies of Smith's correspondence with Rheinstein regarding this project in the National Records of Scotland (NRS) LRCS archived papers. A separate paper considering these archived materials is being prepared.

59 The original remit of the LRCS was later expanded to include consideration of whether a security based upon the English floating charge should be introduced and over what property it should be constituted. See Eighth Report (n 57) at para 1 for the final remit. The LRCS recommended that debtor companies should be able to
} 
introducing a regime of security over moveables "retenta possessione". ${ }^{60}$ Reference was made to the existent restrictive Scots law position, that required delivery in order to create a security right over corporeal moveable property, as well as economic issues that commercial and industrial parties had claimed were caused by this. ${ }^{61}$ Smith acknowledged that Scots law did not have anything corresponding to English securities such as the floating charge and equitable mortgage.

Accordingly, Smith suggested that the LRCS had to consider two questions: ${ }^{62}$

(1) Is it desirable to introduce a system of security over moveable property, ${ }^{63}$ and if so within what limits?

(2) If it is desirable, how should it be done?

It can be presumed that letters in similar terms, posing these same questions, were sent to other consulted experts.

Smith, recognising the experience of Rheinstein and his institute with respect to a wide range of jurisdictions, sought comments in response to the questions. ${ }^{64}$ In turn, Rheinstein provided Smith with some observations but stated that these were limited because he was "not a specialist in the law of personal property" ${ }^{65}$ He added, however, that in Switzerland securities over moveable property had "provoked vivid discussions" and referred to a work that summarised these discussions. ${ }^{66}$

Within the Papers there is a hand-written document that appears to be a version of the observations that were sent to Smith. ${ }^{67}$ Unfortunately, much of the writing is in illegible shorthand. From the words that can be identified, a number of authors and titles of suggested

\footnotetext{
grant a floating charge over all or any part of their property, whether heritable or moveable (see Eighth Report (n 57) at para 55), and this was implemented by the Companies (Floating Charges) (Scotland) Act 1961.

${ }^{60}$ (Where the debtor retains possession of the secured property). This is, however, usually referred to as a nonpossessory security, reflecting a focus on the creditor's side of the transaction. The references to possession and delivery (as well as to machinery, plant and stock) within the letter make clear that the principal focus was corporeal moveable property.

${ }^{61}$ These were issues that were expanded upon in the Eighth Report (n 57).

${ }^{62}$ Letter dated 23 October 1958 (n 12).

${ }^{63}$ In the context, the reference to "a system of security over moveable property" clearly meant a system of nonpossessory security.

${ }^{64}$ Letter dated 23 October 1958 (n 12).

${ }^{65}$ Copy letter dated 4 November 1958 (n 12).

${ }^{66}$ The source referred to is K Oftinger, Kommentar zum schweizerischen Zivilgesetzbuch, vol IV: Das Sachenrecht, Abteilung 2: Die beschränkten dinglichen Rechte, 23 Titel, 2nd ed (1952).

${ }^{67}$ It is unclear whether this document is a copy of the observations that were sent to Smith or only a draft. It is the only document in the Papers that could be the observations referred to.
} 
sources (from various jurisdictions) are cited. ${ }^{68}$ Smith referred to Edinburgh's lack of such sources and stated that "one of the first tasks to be undertaken here is to build up an adequate Law Library of modern Civilian material”. 69 To this end, Smith had requested that the University should invite Howard Drake ${ }^{70}$ from the Institute of Advanced Legal Studies to report on the law library. ${ }^{71}$

With the improvement of Edinburgh University's legal resources in mind, Smith asked whether Rheinstein’s Comparative Law Research Centre could provide a bibliography of "basic Comparative Law materials". Smith added that Edinburgh could not afford "more than a small fraction" of the stocks held by Chicago. ${ }^{72}$ The relatively meagre resources available to Smith must have been a source of frustration when he sought to carry out comparative research. Yet, characteristically, he approached the task of improving the library materials with vigour. Smith's successful efforts to enhance the libraries with which he was connected have been identified by others. $^{73}$

As regards the LRCS project, Rheinstein also served as a first point of contact through whom experts on securities over moveables were identified. Rheinstein suggested that Smith should seek the views of Ernst von Caemmerer, a German jurist at Freiburg. ${ }^{74}$ As noted in the

\footnotetext{
${ }^{68}$ The cited authors and sources are as follows: M Wolff and L Raiser, Sachenrecht, in L Enneccerus, T Kipp, and M Wolff (eds), Lehrbuch des Bürgerlichen Rechts vol 3, 10 Bearbeitung (1957); F Schlegelberger, Rechtsvergleichendes Handwörterbuch für das Zivil- und Handelsrecht des In- und Auslandes vol 5 (1936) at para 583; F Ferrara, L'Ipoteca mobiliare (1932); W Freymann, “Die Rechtslage der modernen Mobiliarhypothek” (1933/1934) 7(4) Rigasche Zeitschrift für Rechtswissenschaft 223; M Cabrillac, La Protection du creancier dans les sûretés mobilières, conventionnelles sans dépossession (1954). Thanks are due to Professor Reinhard Zimmermann and Samuel Fulli-Lemaire for their assistance in identifying these sources. Smith later described Rheinstein's contribution as “most helpful” and stated that it had "ranged over several modern legal systems”: letter from Smith to J H Gibson dated 18 March 1960 in NRS AD61/55.

${ }^{69}$ Letter from Smith to Rheinstein dated 14 November 1958 in Papers.

${ }^{70}$ K H Drake (1915-1967) was the first Secretary and Librarian of the Institute of Advanced Legal Studies of the University of London. He has been described as the "key figure in the development of the Institute during its first twenty years...”: W A Steiner, The Institute of Advanced Legal Studies of the University of London: 1947$1976(2000)$ at 10.

${ }^{71}$ Drake did produce a survey of the library and a number of the sources he recommended were purchased: Library Committee Minutes, 1957-60, Edinburgh University Library (Special Collections). See, in particular, the minutes for the meetings from 12 November 1958 until 25 May 1960.

72 N 69.

${ }^{73}$ See, e.g., Reid (n 9) at $22 \mathrm{f}$ and Willock (n 22) at $2 \mathrm{f}$. In addition, shortly after moving to Edinburgh, Smith joined the Edinburgh University Library Committee and requested the purchasing of sources such as the Tulane Law Review, Louisiana Law Review and South African Law Journal (see n 71, in particular the minutes of meetings on 12 November 1958 and 10 December 1958).

${ }^{74}$ (1908-1985). There is a contribution from Rheinstein in a Festschrift for von Caemmerer published after Rheinstein's death: M Rheinstein, "Vereinbarungen matrimonii causa in den Rechten der Vereinigten Staaten von Amerika”, in H C Ficker et al (eds), Festschrift für Ernst von Caemmerer zum 70. Geburtstag (1978) 987. Von Caemmerer had earlier been an editor of the Festschrift for Rheinstein (n 25). Before Rheinstein departed for the USA in 1933, he and von Caemmerer both worked at the Kaiser-Wilhelm-Institut für ausländisches und internationales Privatrecht in Berlin. The fact that Rheinstein recommended that Smith should contact von Caemmerer is confirmed by Smith's expression of his intention to follow the suggestion (see n 69).
} 
LRCS Report, von Caemmerer was indeed consulted. ${ }^{75}$ In addition, Rheinstein referred Smith’s LRCS request, with respect to American law, to his colleague, Professor Allison Dunham. ${ }^{76}$ Professor Dunham was a leading authority on security rights over moveable property and had earlier been one of the drafters of Article 9 of the Uniform Commercial Code. ${ }^{77}$ Smith awaited Dunham's contribution with interest. ${ }^{78}$

The promised comments from Dunham, in the form of a "Memorandum" concerning “Security Interest over Commercial Chattels in the United States”, were enclosed with a letter dated 17 December 1958 that was sent directly to Smith. ${ }^{79}$ Dunham enthusiastically endorsed the introduction of a non-possessory-type security system over moveable property, for economic reasons, but identified various facets of the public interest that would require consideration, and suggested these could be met, in part, through public recording. ${ }^{80}$ The rest of the Memorandum describes: various security interests then available in the USA; the Uniform Commercial Code, Article 9; ${ }^{81}$ and some of the problems that had to be addressed when drafting this legislation. Again, Dunham's assistance was acknowledged in the LRCS Report. $^{82}$

Rheinstein's contribution to the LRCS project seems to have been limited to the provision of comments on security rights over moveables in modern legal systems (including the citation of relevant sources), the recommendation of von Caemmerer, and the reference of the issue to Dunham. The episode is a demonstration of Smith's eagerness to consult foreign experts in order to support LRCS decision-making. It also highlights the fact that personal contacts were an especially useful means of overcoming difficulties in accessing expertise in other countries in this period. Rheinstein was no doubt one of many such contacts for Smith.

\footnotetext{
${ }^{75}$ Eighth Report (n 57) para 3. Von Caemmerer's comments were drawn upon in Smith’s brief discussion of German law in his "Historical Note”, Appendix I of the Eighth Report at 13f. An English translation of von Caemmerer's contribution is available at NRS AD61/36 (see also n 58).

${ }^{76}$ See copy letter dated 4 November 1958 (n 12). Allison Dunham (1914-1992). For brief biographical details see B Lambert, “Allison Dunham, 78, a Professor Who Helped Make Laws Uniform”, New York Times (28 June 1992) 32.

${ }^{77}$ See, e.g., A Dunham, “Reflections of a Drafter: Allison Dunham” (1982) 43 Ohio St LJ 569. G Gilmore, Security Interests in Personal Property vol I (1965) ch 9, also provides some background on UCC Article 9 and its early drafting history.

${ }^{78} \mathrm{~N} 69$.

${ }^{79}$ Copy letter from A Dunham to Smith copied to Rheinstein dated 17 December 1958 in Papers.

${ }^{80}$ Copy Memorandum from Dunham to Smith, undated, in Papers.

${ }^{81}$ By this point UCC Article 9 had only been adopted in three states (Pennsylvania, Massachusetts and Kentucky). It was subsequently adopted in all US states, the last of which was Louisiana, where it became effective on 1 January 1990. Smith was already aware of the UCC by September 1957: copy letter from A E Sutherland to T B Smith dated 23 September 1957 in Sutherland Papers (n 34). For consideration of UCC Article 9 from a Scots law perspective, see Scottish Law Commission Discussion Paper on Moveable Transactions (Scot Law Com DP No 151, 2011) ch 13. See also Scottish Law Commission, Report by Working Party on Security over Moveable Property (1986), better known as the "Halliday Report".

${ }^{82}$ Eighth Report (n 57) para 3. A copy of Dunham’s memorandum is also available at NRS AD61/36.
} 


\section{(3) The legal nationalist?}

Scottish legal nationalism has often been considered an integral part of Smith's identity. Indeed, Professor Kenneth Reid has written that Smith was "proud to be a legal, and indeed a cultural, nationalist”. ${ }^{83}$ The nature of Smith's nationalism has been analysed by Professor Gretton, who paints a more nuanced picture. ${ }^{84}$ Smith was certainly a passionate advocate of the distinctiveness and importance of Scots law in the face of a perceived threat from English law. ${ }^{85}$ Correspondence within the Papers provides an example of Smith acting in such a role within an international context.

Smith wrote to Rheinstein on 25 November 1958 enclosing a copy of a letter that he had sent to Drake de Kay, Senior Editor of the Encyclopedia Americana. ${ }^{86}$ Smith had taken offence at the limited space of 500 words offered to him, for an article on Scots law, in comparison to a longer England-focused article on the judicial system of Great Britain.

Rheinstein's assistance was sought by Smith in order to convince de Kay that "whatever some of the English may think, we have not become part of England yet". ${ }^{87}$ Such a comment, in its relevant context, is consistent with Smith's view that Scots law and nationhood were intrinsically linked. ${ }^{88}$ Within the letter to Rheinstein, Smith added, perhaps only slightly flippantly, that a case could be made for Scotland being considered the senior member of the Union as it had provided the royal dynasty. However, he noted that Scotland was "alas, not the wealthiest nor more populous" part. ${ }^{89}$ A belief was also expressed by Smith that many Americans with Scottish ancestry would wish to know more about Scotland than the permitted length of the article would allow.

Within his letter to de Kay, Smith was forthright, stating that de Kay had "been sold a very English outlook on the judicial system of Great Britain”. ${ }^{90}$ Smith pointed out, inter alia, that the article in question did not refer to the "equal recognition" that was accorded to the legal systems of Scotland and England by virtue of the Union of $1707 .{ }^{91}$

\footnotetext{
${ }^{83}$ Reid (n 9) at 16.

${ }^{84}$ Gretton (n 56). See also: Osler (n 1), MacQueen (n 22), and L Farmer, "Under the Shadow over Parliament House: The Strange Case of Legal Nationalism”, in L Farmer and S Veitch (eds), The State of Scots Law: Law and Government after the Devolution Settlement (2001) 151.

${ }^{85}$ See, e.g., Smith "Strange gods” (n 12), and T B Smith, “Legal imperialism and legal parochialism” 1965 Jur Rev 39.

${ }^{86}$ Letter from Smith to Rheinstein dated 25 November 1958 in Papers.

${ }^{87}$ Ibid.

${ }^{88}$ See, e.g., Smith (n 18) at vii.

${ }^{89} \mathrm{~N} 86$.

${ }^{90}$ Copy letter from Smith to D de Kay dated 25 November 1958 in Papers.

${ }^{91}$ See also Smith’s earlier article: “The Union of 1707 as Fundamental Law” (1957) Public Law 99. It was later republished in Smith (n 17) at 1.
} 
According to Smith, English law in 1707 was "in a most formalistic and unsatisfactory condition” compared with Scots law which, he noted, was aligned with the Civilian systems in continental Europe, especially France and the Netherlands. He added that Lord Mansfield, who “rationalised” English commercial law, had to use the works of Scottish writers, including Stair and Mackenzie, "for any rational statement of principle" when he was a student. ${ }^{92}$ Although Mansfield had a Scottish background, and therefore his use of Scottish sources is not entirely unexpected, it would be misleading to suggest that he did not also rely upon a range of nonScottish sources. ${ }^{93}$ In any event, Smith acknowledged the considerable progress of AngloAmerican law since Mansfield's time, ${ }^{94}$ but stressed that Great Britain still had "two entirely separate legal systems": the English Common Law and Scots law, which was "based mainly on the Civil Law". ${ }^{95}$ The amplification of Scots law's Civilian heritage, its supposed early modern sophistication relative to English law, and its continued independent identity all feature heavily here.

It would not be fair to Smith to suggest that his only intention was to disparage English law whilst eulogising the law of Scotland. Rather, he was challenging perceived Anglo-centrism and sought permission for a more extensive Scots law article in order to address this. To support his argument he drew upon Scots law’s separateness, pointing out that it differed markedly from English law. Smith stated that he did not expect equal treatment with England. He simply desired that space should be offered for an "adequate article” on Scots law or that it should be made clear that only the English judicial system was being considered. ${ }^{96}$

In order to lend further weight to his position, Smith asked de Kay to communicate with Rheinstein, Professor Arthur Sutherland ${ }^{97}$ of Harvard, or any member of Tulane Law School ${ }^{98}$ prior to deciding upon a course of action. ${ }^{99}$ Rheinstein was well aware of Scots law's distinctiveness through his contact with Smith. This was also true for Sutherland. ${ }^{100}$ The views

\footnotetext{
${ }^{92}$ N 90. Smith also referred to this in "The common law cuckoo" (n 20) at 91 in the Studies Critical and Comparative republished version.

${ }^{93}$ In fact, a source cited by Smith in "The common law cuckoo" (n 20) (see fn 91) mentions Mansfield's use of a number of sources written by jurists from different countries: J Campbell, The Lives of the Chief Justices of England vol II (1849) 327-328. Consequently, by referring only to Mansfield's reliance upon Scottish writers such as Stair and Mackenzie, Smith seems to have been selectively using the evidence available in order to support his own ideological position.

94 This may have been a comment made with the nationality of his correspondent in mind.

${ }^{95} \mathrm{~N} 90$.

${ }^{96}$ Ibid.

97 Smith also corresponded with Sutherland (see n 34).

${ }^{98}$ Smith had, of course, spent time at Tulane University (see above).

${ }^{99} \mathrm{~N} 90$.

${ }^{100}$ Sutherland also alluded to his Scottish heritage in correspondence with Smith: see copy letter from Sutherland to Smith dated 19 February 1957 in Sutherland Papers (n 34). Although see, in the same collection, Sutherland's scepticism about how much Civil Law remained in Louisiana's system: copy letter from Sutherland to Smith dated 6 March 1957.
} 
of the Tulane Law School members would, most likely, have chimed with those of Smith, given Louisiana's status as a mixed legal system. ${ }^{101}$

It is unclear whether Rheinstein, or anyone else for that matter, wrote in support of Smith's position or whether that was even necessary. Smith's protestations were apparently somewhat successful as he ultimately did contribute an article on Scots law for the Encyclopedia Americana that was around double the length of the original proposal. ${ }^{102}$ In this article he makes reference, inter alia, to Scotland’s Civilian “foundations” (excluding land) and suggests that it was indirect English influences that caused Scots law to become a mixed system. ${ }^{103}$

Smith sought to address observed unfair treatment of Scots law by invoking the influence of his network of American contacts, including Rheinstein. Although there is insufficient evidence to say whether or not Smith received active assistance, his actions here provide one, fairly minor, example of how he attempted to utilise international allies in his campaign for the protection and promotion of the law of Scotland.

\section{(4) Making it in America}

Smith also called upon Rheinstein's expertise with respect to publishing in the USA. In a letter dated 20 January 1961 Smith informed Rheinstein that a collection of around thirty of his papers might be published in book form under a title like "Studies Critical and Comparative on the Law of Scotland". ${ }^{104}$ The papers that were expected to be included were articles already published in France, South Africa, the UK, and the USA, and unpublished Tulane lectures on the "Common Law of Obligations in Mixed Jurisdictions".

The Edinburgh publishers ${ }^{105}$ only wished to proceed, however, if there was "a reasonable market” in the USA, even if this only amounted to around one thousand copies. Smith also specified that the publishers were interested in combining with an American publisher. Consequently, Smith asked for Rheinstein's advice. ${ }^{106}$ In Rheinstein's view, if the

\footnotetext{
101 N 90.

102 The published article is still therefore relatively short. It has not been possible to acquire the 1959 version of Encyclopedia Americana (International Edition) vol 24, which first featured Smith's article (see Anderson (n 3)). The 1959 American published version of this volume still contained an article entitled "Scotch or Scots Law" by E F Donovan (at 427-428). For Smith’s article, see e.g. T B Smith, “Scotland - Law” in the more widely available Encyclopedia Americana (International Edition) vol 24 (1965) 445-456.

103 Ibid at 445. Subsequent historical research has served to undermine Smith's interpretation: see W D H Sellar, "Scots law: mixed from the very beginning? A tale of two receptions" (2000) EdinLR 3.

${ }^{104}$ N 53. These essays were ultimately published as Studies Critical and Comparative (n 17) but only numbered sixteen in total plus a new introduction.

105 Presumably W Green \& Son Ltd, given that they eventually co-published the work.

106 N 53.
} 
title of the book were to suggest an exclusive application to Scots law then the prospect of sales in the USA would be "limited". ${ }^{107}$ By way of explanation, he referred to the interest of Americans still being "localized", despite the recent "vigorous growth of comparative law and international legal relations”. 108

In his view, potential purchasers would be libraries of "respectable” law schools, some bar associations and court libraries, bar members whose interests were not limited to those of a “vocational character” and a "perhaps considerable” number of American lawyers with Scottish ancestry. Nevertheless, Rheinstein expressed doubt as to whether total sales would even reach five hundred copies. If, however, the book was to be released under a title which did not indicate a restriction to Scotland, then sales of around one thousand could reasonably be expected. To assist with this, Rheinstein proposed a title such as "Common Law and Civil Law”, followed by smaller print stating, "as illustrated by the law of Scotland”, 109

In response, Smith specified that his primary intention was "promoting interest in the law of Scotland" and therefore he was not overly concerned about the volume of American sales. ${ }^{110}$ Although he preferred to include a reference to Scotland in the title of the work, Smith acknowledged that this could restrict its audience. He therefore agreed to “ponder” Rheinstein's suggested title or something similar, noting that it would be appropriate as a number of the articles referred to mixed systems other than Scotland. ${ }^{111}$

The eventual title, Studies Critical and Comparative, retained the first part of the original title but with the reference to Scotland removed, thus avoiding a perception of exclusivity. Smith's introduction to the work, which surveys mixed legal systems throughout the world, may also have been written with a view to attracting a larger readership outside Scotland. ${ }^{112}$

With respect to publishing in the USA, Rheinstein wrote that the two general possibilities were to use a commercial publisher or a university press, and mentioned some examples of each. ${ }^{113}$ Although Rheinstein had reservations about whether commercial publishers would be interested in publishing the book, he advised that Oceana Publications in New York were “venturesome” and had previously released law books “judged pessimistically”

\footnotetext{
${ }^{107}$ Copy letter from Rheinstein to Smith dated 31 January 1961 in Papers.

108 Ibid.

109 Ibid.

${ }^{110}$ Letter from Smith to Rheinstein dated 8 February 1961 in Papers.

111 Ibid. He would have had in mind articles such as "Scots law and Roman-Dutch Law" (n 20) that were eventually published in Smith (n 17).

112 Smith, "Introduction" (n 20).

${ }^{113}$ N 107. The university presses Rheinstein mentioned were: Chicago University Press; Harvard University Press; Louisiana University Press; Michigan University Press; and Oxford University Press (New York branch).
} 
by other publishers. ${ }^{114}$ Smith was consequently of the view that Oceana should be contacted first. ${ }^{115}$ Rheinstein's suggestion of Oceana as potential publishers proved fruitful as they ultimately co-published the work.

\section{(5) Sources of law}

A feature of Smith's contact with Rheinstein was his use of the connection to acquire details of the law in the USA and elsewhere. We have already encountered this within the context of the reform of security over moveable property. The correspondence discloses that this was also true in other areas.

In June 1959 Smith wrote to Rheinstein seeking information about criminal law, which continued to be of "considerable interest" to him even though civil law was his principal focus. ${ }^{116}$ His request was, in fact, specifically related to criminology. Smith asked Rheinstein to place him in contact with a criminologist who could recommend sources regarding the "criminality of women in America” and the "penal treatment of women prisoners". ${ }^{117}$ Given the subject matter, it is possible that the information requested was actually, or additionally, to be used by Smith's wife, an expert in the field of female offending. ${ }^{118}$

Following Smith's request, Rheinstein wrote to Professor Herbert Wechsler ${ }^{119}$ at Columbia University, stating that he was unable to provide the information sought by Smith but asked whether Wechsler could do so. ${ }^{120}$ Smith acknowledged Rheinstein's assistance in a subsequent letter. ${ }^{121}$ Again, this serves to demonstrate Smith using Rheinstein as an intermediary contact. Through Rheinstein, Smith could access a wider network of scholars, with expertise in various areas of law.

\footnotetext{
114 Ibid.

115 N 110.

${ }^{116}$ N 46. Smith's ongoing interest was referred to in a later letter in which he referred to his admiration for $H$ von Hentig, Die Strafe, 2 vols (1954-1955) and his anticipation of a work from the same author that was first published as Die Kriminalität der lesbischen Frau (1959): see letter dated 18 June 1959 (n 33). The obvious conclusion to draw from this is that Smith could competently read and understand German sources. It should be noted though that an LRCS letter from the previous year discloses that Smith was not always comfortable translating technical legal German and therefore a formal translation of von Caemmerer's letter into English was sought: letter from Smith to J H Gibson dated 7 January 1958 in NRS AD61/55 (and see n 75).

117 N 46.

${ }^{118}$ As indicated by the following book published a few years later: A D Smith, Women in prison: a study in penal methods (1962). In correspondence written while he was in America in 1962, T B Smith stated that his wife was the "British expert on women delinquents, and would be most interested to visit penal institutions for adult women offenders...”: copy letter dated 31 October 1962 (n 37).

119 (1909-2000). See D L Shapiro, “Herbert Wechsler - A Remembrance,” (2000) 100(6) Columbia LR 1377.

120 N 52.

${ }^{121}$ See letter dated 18 June 1959 (n 33).
} 
Rheinstein and Smith also shared their own writings in areas of common interest. For instance, in one letter Smith thanked Rheinstein for his "stimulating offprints". ${ }^{122}$ Apparently, Rheinstein's offprint on “Judicial and administrative control of the liquidation of decedents' estates”123 had arrived at a particularly suitable time, as Professor Zepos ${ }^{124}$ of Athens had been enquiring with Smith about this issue in relation to Scots law. ${ }^{125}$ In turn, Smith gave Rheinstein a copy of the response sent to Zepos. ${ }^{126}$ This was one example of Smith providing information about Scots law to Rheinstein. ${ }^{127}$ The document appears to have been received with interest by Rheinstein, as he was reviewing a new American book relating to the same field of law. ${ }^{128}$

The correspondence shows that Smith used his connection as a medium through which he obtained sources (including offprints), both directly from Rheinstein and indirectly via individuals recommended or contacted by Rheinstein. All of this is, of course, typical within the context of a professional relationship between academics. It can therefore be safely presumed that Smith had a number of other contacts from whom he derived assistance in similar ways.

\section{(6) Scholars and teaching}

Within the correspondence we are provided with an intriguing glimpse into Rheinstein and Smith’s perceptions of Civil Law teaching as well as their views on particular legal scholars.

\footnotetext{
${ }^{122}$ Letter dated 19 November 1960 (n 47).

123 The relevant article was most probably M Rheinstein, “Judicial and Administrative Control of the Liquidation of Decedents' Estates” in Rapports généraux au Ve Congrès international de droit comparé, Bruxelles, 4-9 août 1958 vol I (1960) 229.

124 (1908-1985). Smith was later one of the contributors to a Festschrift in honour of Zepos: T B Smith, “Solatium”, in E von Caemmerer et al (eds), Xenion: Festschrift für Pan J Zepos, Anlässlich seines 65 Geburtstages am 1 Dezember 1973 (1973) vol 1 589. See also the obituary for Zepos in French at P Dimakis, “Panayotis Zepos (1908-1985)” (1986) 103 Zeitschrift der Savigny-Stiftung für Rechtsgeschichte (Romanistische Abteilung) 659.

125 Letter dated 19 November 1960 (n 47).

126 The letter to Zepos was written in collaboration with a colleague with "special knowledge of the Law of Wills and Land”. Before answering particular questions posed by Zepos on issues such as the disinheritance of children and testamentary formalities, Smith suggested that it was "paradoxical” that Scotland, "although basically a Civil Law system” had not followed other such systems with respect to universal succession and immediate transfer to heirs upon death: copy letter to P J Zepos dated 19 November 1960 enclosed with letter from Smith to Rheinstein of same date (n 47).

${ }^{127}$ Another example is the provision of the details contained within the letter to de Kay that Smith copied to Rheinstein (see n 90 above). In addition, it seems from the content of his letter to Rheinstein dated 10 December 1960 that Smith may have attached the offprint of "Scots law and Roman-Dutch law" (n 20) (however, no such document is held within the Papers). See also M Rheinstein, "How to Review a Festschrift" (1962) 11 AJCL 632 at 643-644 where Rheinstein provides a brief review of T B Smith, "Full circle: the law of Occupiers' Liability in Scotland”, in K H Nadelmann et al (eds), XXth Centenary Comparative Conflicts Law: Legal Essays in Honor of Hessel E Yntema (1961) 128.

${ }^{128}$ N 48. The book referred to was W D MacDonald, Fraud on the Widow's Share (1960); reviewed by Rheinstein at (1960-1) 59 Mich LR 806.
} 
Smith had informed Rheinstein, in November 1960, that he required replacements to teach his classes at Edinburgh for the duration of his time at Harvard (in 1962-1963). The relevant classes were "an introductory course on Civil Law and Comparative Law" and a corresponding honours course "for a favoured few". ${ }^{129}$ Smith added that his approach "to the Civil Law" was to "start with Justinian more or less, instead of finishing with him as may be appropriate in countries like England where the interest in Roman law is primarily historical”. ${ }^{130}$ What seems to have been important for Smith was to use Justinianic Roman law as a starting point from which historical developments stretching to contemporary law could be navigated.

Smith enquired whether Rheinstein could identify a scholar who might be free to replace him. He added that the honorarium that Edinburgh could provide would be "altogether inadequate" in American salary terms and therefore he expected that an American scholar would, in all likelihood, need to be supported by an American foundation. ${ }^{131}$ In light of difficulties such as this, Smith's success in attracting foreign scholars to Scotland is to his further credit. Smith informed Rheinstein that he had already thought of Ferdinand Stone and Paul Crépeau as potential replacements. ${ }^{132}$ It is notable that both of these scholars were based at universities in mixed legal systems, at Tulane (Louisiana) and McGill (Quebec) respectively.

Rheinstein proposed various individuals to Smith. ${ }^{133}$ The scarcity of talent in the USA, in his view, caused him to state that the only law school teacher in that country "who would really be competent” to teach Roman law pre-Justinian (despite Smith's comments noted above) was Arthur A Schiller of Columbia University. For Civil Law after Justinian, Rheinstein thought that possibly only Jack Dawson and Arthur von Mehren, both from Harvard, would be suitable. ${ }^{134}$ Smith doubted whether Harvard would release Dawson or von Mehren and although he was praiseworthy about Schiller he was already aware of his unavailability. ${ }^{135}$ One nonAmerican recommended by Rheinstein was Erich Genzmer, a German scholar. ${ }^{136}$ Genzmer was also someone who Smith knew and had corresponded with in the past. ${ }^{137}$

\footnotetext{
${ }^{129}$ For particular details of these courses for the 1962-1963 session, when Smith was at Harvard, see Edinburgh University Calendar 1962-1963, Edinburgh University Library (Special Collections) at $93 \mathrm{f}$.

${ }^{130}$ Letter dated 19 November 1960 (n 47).

131 Ibid.

132 Ibid.

${ }^{133} \mathrm{~N} 48$. Rheinstein appears to have hand-written, on the letter from Smith, names of other individuals who could provide the necessary assistance. The written names not mentioned in the subsequent letter are Cowen (Cape Town), Dainow (Louisiana State), and Wieacker (Göttingen).

134 Ibid.

${ }^{135}$ Letter from Smith to Rheinstein dated 10 December 1960 in Papers.

${ }^{136}$ N 48. E Genzmer (1893-1970). Misspelt as “Grenzmer” in the letter. See H Coing, "Erich Genzmer” (1971) 88 Zeitschrift der Savigny-Stiftung für Rechtsgeschichte (Romanistische Abteilung) 574.

${ }^{137} \mathrm{~N} 135$.
} 
A number of the individuals recommended by Rheinstein were based in South Africa: $\mathrm{J}$ C de Wet ${ }^{138}$ (Stellenbosch); Ben Beinart ${ }^{139}$ (Cape Town); Paul van Warmelo ${ }^{140}$ (Pretoria); and J E Scholtens ${ }^{141}$ (Witwatersrand). Rheinstein had visited the country the previous summer and was "thoroughly impressed with the caliber of learning" there. In even more glowing terms, he described South Africa as the place where "one can find those scholars who, at present, are perhaps the most competent of all to teach Roman Law both Pre- and Post- Justinian”. ${ }^{142}$

Smith was, of course, familiar with both the standard of scholarship in South Africa and the prominent jurists based there. Arrangements had already been made for Beinart, De Wet, and Scholtens to teach at Edinburgh University, ${ }^{143}$ and Smith stated that Van Warmelo would also be a "most welcome" visiting professor. ${ }^{144}$ Smith had previously "extended an open invitation to South African scholars who wished to teach in Scotland" and he believed that the law in South Africa was "the closest system” to Scots law. ${ }^{145}$ The development of links between Scotland and South Africa was something that Smith was passionate about. However, promoting such links against the background of mounting apartheid-related political problems in South Africa, especially after the Sharpeville massacre in 1960, was highly contentious and doomed to failure; by the mid-1960s the regular visits from academics had stopped. ${ }^{146}$

In spite of Rheinstein's suggestions, the academics that eventually taught Smith's classes at Edinburgh in 1962-1963 were those Smith had first considered, Crépeau and Stone. ${ }^{147}$ The unavailability of many of the suggested replacements and the fact that others were already scheduled to visit certainly served to limit the possibilities. As a general point, Smith's encouragement of visits to Scotland by foreign scholars must have helped him (and perhaps other Scottish lawyers) to develop professional relationships with such individuals.

\footnotetext{
${ }^{138}$ In his review of Reid \& Carey Miller (eds), Mixed Legal System (n 1) at (2006) EdinLR 164 at 167, Jacques du Plessis compares Smith and De Wet. For further information regarding De Wet, see J E du Plessis and G Lubbe (eds), A Man of Principle (2013).

${ }^{139}$ Smith contributed to a Festschrift in honour of Beinart: T B Smith, “Transfer of property in corporeal moveables by inter vivos acts United Kingdom - Scotland. Section II.A.s - Droit Civil (Le transfert de la propriété par actes entre vifs.)”, in W de Vos et al (eds), Essays in Honour of Ben Beinart vol III (1979) 39.

${ }^{140}$ Smith later contributed to a publication in honour of van Warmelo: T B Smith, “Authors and authority” in J van der Westhuisen et al (eds), Huldigingsbundel Paul van Warmelo (1984) 180. The original version of the article was published at (1972) 12 JSPTL 3.

${ }^{141}$ Smith was already aware that Scholtens had decided to return to the Netherlands (n 135).

${ }^{142} \mathrm{~N}$ 48. It is interesting to note that Smith and Rheinstein both later served on the international advisory board for the Comparative and International Law Journal of Southern Africa: see, e.g., vol 1 (1968).

143 The men were scheduled to visit at various points between 1960 and 1962. For details of some other academics who visited Edinburgh during the period, see Reid (n 9) at 23 and Reid (n 22) at $11 \mathrm{ff.}$

${ }^{144} \mathrm{~N} 135$.

145 Ibid. As noted above, Smith had held visiting professorships in South Africa and had also attended the Cape Town Law Faculty centenary celebrations in 1959 where he delivered the lecture published as "Scots law and Roman-Dutch law” (n 20).

${ }^{146}$ See Reid (n 9) at 19 f; Reid (n 22) at 15; and Carey Miller (n 41) at 177 ff.

${ }^{147}$ Lord Hope refers, positively, to the lectures delivered by Crépeau and Stone (n 1) at xi.
} 
The last two pieces of correspondence between Rheinstein and Smith relate to Professor Feenstra ${ }^{148}$ from the University of Leiden. The Dutch scholar had previously taught a course at Edinburgh $^{149}$ and was expecting to visit Chicago in late April or early May 1965. Smith therefore asked Rheinstein to "take an interest in" Feenstra and suggested that the Dutchman could deliver lectures on topics such as the "Reception of Roman law in the Netherlands" and "Liability for causing the death of a free man". ${ }^{150}$ Rheinstein was already aware of Feenstra "by name and reputation" and considered that the visit would be a "great pleasure". ${ }^{151}$ Given Rheinstein's existing knowledge of Feenstra and the fact that the Dutchman seems already to have made plans to travel to Chicago, Smith's intervention was probably of little consequence. However, it does indicate his willingness to use connections, such as the one with Rheinstein, to support and recommend other contacts of his. ${ }^{152}$

\section{E. CONCLUSION}

The discussed correspondence between Rheinstein and Smith gives us a rare opportunity to consider Smith's interaction with a renowned international academic during a significant time in his career. Although the letters reveal friendliness between the men, the principal purpose of the relationship for Smith seems to have been its instrumental nature. The correspondence therefore does not contain profound intellectual discussion but something rather more prosaic. Smith contacted Rheinstein when he believed that he could obtain practically useful help, for example in relation to publishing on Scots law in the USA, the reform of security rights over moveable property in Scotland and in order to identify suitable scholars to teach his classes at Edinburgh University. Such requests were the primary driving force behind the correspondence. Rheinstein was generally willing to assist, but the outcomes in each case were of varying value for Smith.

\footnotetext{
${ }^{148}$ For biographical details, see L Winkel “In Memoriam Robert Feenstra (1920-2013)” (2013) 34 Grotiana 1.

149 On "the law of delict traced from Justinian to modern times".

${ }^{150}$ Letter dated 23 November 1964 (n 49).

${ }^{151}$ Copy letter dated 7 December 1964 (n 49). The only caveat to this was that Rheinstein hoped Feenstra would arrive in Chicago prior to the end of April, as Rheinstein was scheduled to teach in Munich on 1 May 1965.

152 On a related note, Michael Meston, a former pupil of Smith’s, attended Chicago University as a JD student in the late 1950s: see D Carey Miller, "Michael Meston: an Appreciation” The Herald (27 March 2013). I am grateful to the anonymous peer reviewer for this reference. Meston was taught at Chicago by Rheinstein, but Smith does not appear to have played a direct role in Meston's decision to go to Chicago. Nevertheless, Smith's involvement cannot be ruled out entirely. I wish to express thanks to Professor Meston’s widow, Doris Meston, for providing this information and to Professor David Carey Miller for relaying it to me.
} 
It is no doubt true that Smith engaged in correspondence, for similarly functional purposes, with a number of other scholars in different jurisdictions. The various academics referred to in the Rheinstein-Smith letters seem to have also been members of the international network of legal scholars of which Smith and Rheinstein were both very much part. This was an extensive community that could be used for the provision of information, advice, and support. The documentation considered in this article highlights how, and for what purposes, Smith drew upon one particular individual within this network.

Given the existence of the Papers, identifying Rheinstein's contacts and the content of his correspondence is an easier task than is the case for Smith. ${ }^{153}$ Although it is well-known that Smith was in contact with a variety of scholars around the world, and that these individuals helped to forge his reputation and legacy, much of the written communication between them and Smith has been lost. As a result, the examination and analysis of correspondence that is available is of particular worth. By doing so we can better understand one of Scots law's most eminent figures.

153 As noted above (n 41), there is a collection of Smith’s papers held at the University of Edinburgh; however, these papers contain only a limited volume of correspondence. 